\title{
AIRBORNE MEASUREMENTS OF THE SIZE DISTRIBUTION \\ AND THE CONDENSATION AND ICE NUCLEATING ABILITY \\ OF PARTICLES PRODUCED BY AgI CONTAINING \\ PYROTECHNICS AND ACETONE SOLUTION BURNERS
}

by

A. J. Alkezweeny and L. F. Radke

Oral Presentation at Eighth International Conference on Nucleation of the IAMAP (ICCP) Leningrad, U.S.S.R.

and

for publication in the Proceedings

August, 1973

\author{
BATTELLE-NORTHWEST \\ Battelle Memorial Institute \\ Pacific Northwest Laboratories \\ Richland, Washington
}

This paper is based on work performed under U. S. Atomic Energy Commission Contract No. AT (45-1) 1830 


\section{DISCLAIMER}

This report was prepared as an account of work sponsored by an agency of the United States Government. Neither the United States Government nor any agency Thereof, nor any of their employees, makes any warranty, express or implied, or assumes any legal liability or responsibility for the accuracy, completeness, or usefulness of any information, apparatus, product, or process disclosed, or represents that its use would not infringe privately owned rights. Reference herein to any specific commercial product, process, or service by trade name, trademark, manufacturer, or otherwise does not necessarily constitute or imply its endorsement, recommendation, or favoring by the United States Government or any agency thereof. The views and opinions of authors expressed herein do not necessarily state or reflect those of the United States Government or any agency thereof. 


\section{DISCLAIMER}

Portions of this document may be illegible in electronic image products. Images are produced from the best available original document. 
AUTHOR

Atmospheric Analysis Section ATMOSPHERIC SCIENCES DEPARTMENT

Oral Presentation at

For Publication in

Date

BATTELLE-NORTHWEST

Battelle Memorial Institute

Pacific Northwest Laboratories

Richland, Weshington

This paper is based on work performed under U. S. Atomic Energy Commission Contract No. AT (45-1) 1830

Battelize is not engaged in research for advertising, sales promotion, or publicity, and this report may not be reproduced in full or in part for such purposes 


\section{Airborne Measurements of the Size Distribution and the Condensation and Ice Nucleating Ability of Particles Produced by AgI Containing Pyrotechnics and Acetone Solution Burners}

A. J. Alkezweeny ${ }^{1}$ and L. F. Radke ${ }^{2}$

\section{ABSTRACT}

Airborne measurements using two aircraft were made of the size distribution and nucleating activity of particles generated by both AgI pyrotechnic flares and $\mathrm{AgI}-\mathrm{NH}_{4} \mathrm{I}$. acetone solution bumers. It was found that the pyrotechnic flares produced particles generally larger than 0.1 wn in diameter which were good cloud condensation nuclei. Particles produced by the AgI - acetone solution burners were less than $0.1 \mu \mathrm{m}$ in diameter and, by comparison with the pyrotechnic flares in terms of mass of AgI consumed, relatively inefficient both as ice nuclei and cloud condensation nuclei.

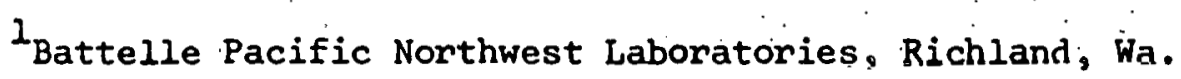
${ }^{2}$ Dept. of Atmospheric Sciences, University of Washington, Seattle Wa. 


\section{Introduction}

It appears from both theoretical studies and experimental measurements that the ice nucleating ability of a particle is dependent upon its size and its ability to act as a condensation nucleus in addition to other physical and chemical factors. Previous measurements of the size distribution have been conducted in the laboratory. However, the size distribution of aerosol particles produced by a generator mounted on an aircraft might be quite different from that produced by a ground-based generator since the degree of coagulation depends on ventilation. In the case of generation from an aircraft the airspeed, mechanical turbulence, and wing tip vortices will dictate the degree of coagulation. Previous workers have attempted to simulate these conditions in special wind, tunnels (Steele and Sciacca, 1966; Mossop and Tuck-Lee, 1968; Donnan, et al., 1971; and Gerber and Allee, 1972). However, Dingle (1969) in measuring the size distribution of pyrotechnically generated $\mathrm{InCl}_{3}$ particles found that the size distribution measured in a wind tunnel was significantly different from that measured behind the "prop-wash" of a stationary anchored aircraft. Therefore, to more completely' understand the nature of AgI aerosols produced from airborne generators it is clear that the size distribution and nucleating activity of the particles should be determined with airborne instrumentation.

In this report, data are presented on the particle size distribution and CCN activity of two different ice nucleus generators which were mounted on an aircraft and operated in flight.

\section{The experiment}

The ice nucleus generators were mounted under the wings of the Battelle Cessna $4 i l$ aircraft. One generator produced ice nuclei by means of pyrotechnic AgI flares . (Colspan mixture CSP-009A) and the other generator was a $\mathrm{AgI}-\mathrm{NH}_{4} \mathrm{I}$ acetone solution burmer (the mixture used was similar to that described by Henderson, 1972, see Table I). 
Measurements on the effluents from these two sources were made from the University of Washington's Douglas B-23 research aircraft. The two aircraft were flown in precision formation at constant altitude and airspeed separated by about $800 \mathrm{~m}$. Each experiment was carried out in a region of air with a low and fairly stable aerosol content.

The B-23 carried its normal state parameter instrumentation (see Hobbs, et al., 1971) and also the following instruments for aerosol measurements:

(1) An automatic $\mathrm{CCN}$ counter (Radke and Turner, 1972) operated at 0.5 per cent supersaturation.

(2) A continuous ice nucleus counter (Mee Industries, 1972) operated at $-20 \mathrm{C}$.

(3) An optical particle counter (Royco, Model 220) with a sample flow rate of $0.5 \cdot \mathrm{l} \mathrm{sec} \mathrm{sec}^{-1}$ and capable of simultaneously sizing particles Alkezweany (173) in the range of 0.3 to $5 \mu \mathrm{m}$ diameter. ${ }_{n}$. This counter was equipped with a premixing chamber and dilution system to prevent coincidence counting when measuring concentrated aerosols.

(4) A Whitby aerosol analyzer, which was a commercial version of the ion mobility analyzer described by Whitby and Clark, 1966 (Thermo Systems, Inc., Model 3000). In principle, this device is capabie of measuring the aerosol number spectra from 0.015 - 0.5 . um diameter.

(5) An integrating nephelometer (Charlson, et al., 1969) which has been shown by Ensor, et al., (1972) to measure the total light scattering of particles larger than $0.1 \mu \mathrm{m}$ diameter.

It was found in preliminary experiments that the plume generated by the pyrotechnic flares attached to the Cessna 411 was not mixed by the wing tip vortices when the two aircraft were separated by up to $1 \mathrm{~km}$. The cross section of the plume was visually estimated to be $2-3 \mathrm{~m}$ in diameter which was far too small for the B-23 to remain 
centered in for the desired 5 minute intervals. Convolution of the plume by. inhomogeneities in atmospheric motions prevented increasing the distance between the two aircraft much beyond $1 \mathrm{~km}$. This problem was solved by applying $15^{\circ}$ of control flap on the Cessna which resulted in a plume approximately $20 \mathrm{~m}$ wide at $0.8 \mathrm{~km}$ separation (the Cessna wingspan is $13 \mathrm{~m}$ ). Because the plume from the acetone burners was almost invisible it was assumed that it behaved identically to the pyrotechnic plume.

\section{Results and discussion}

The first full-scale experiment was conducted on September 28, 1972, at an altitude of $1,600 \mathrm{~m}$ MSL, just east of Dungeness, Washington. This location is west of most sources of continental pollution and the background concentration of less than $100 \mathrm{CCN} \mathrm{cm}^{-3}$ suggests that the air was of essentially marine origin. The concentration of particles larger than $0.3 \mathrm{\mu m}$ diameter was very low, less than $0.3 \mathrm{l}^{-1}$. Fig. 1 shows the concentrations of $C \mathrm{CN}$ active at 0.5 per cent supersaturation, the aerosol light scattering coefficient, and the measurement of the turbulent energy produced by the Cessna during a portion of the run. The background aerosol is seen to contribute less than 5 per cent of the aerosol measurements in the plume from the pyrotechnics. During practice runs behind the Cessna with no particle generators operating the exhaust aerosol was found to cause only a slight increase over the background aerosol concentrations. These results suggest that the pyrotechnically produced particles are both effective $C C N$ and a substantial portion of them are larger than $0.1 \mu \mathrm{m}$.

Fig. 2 shows size measurements of the AgI particles produced by the pyrotechnics over the range of 0.015 to $5 \mu \mathrm{m}$ averaged over the entire sample. These data are contrasted with a pyrotechnic ( $\mathrm{LW}-83)$ burned in a wind tunnel and measured with a similar instrumentation system (Grant, 1971). Since these pyrotechnics are not identical and the tunnel dilution factor is uncertain the comparisons are only suggestive, but they suggest, on the basis of slope alone, that the pyrotechnic burned on the aircraft may produce more small particles and fewer particles larger than $0.3 \mu \mathrm{m}$ diameter. 
The second experiment was made on October 5, 1972, at $2300 \mathrm{~m} \mathrm{MSL} \mathrm{over} \mathrm{the} \mathrm{San}$ Juan Islands in the northwestern portion of Washington State. During this experiment the AgI - $\mathrm{NH}_{4} \mathrm{I}$ - acetone solutions were burned first and then the pyrotechnic flares. The aerosol generated by the acetone burners was virtually invisible. The most practical way of remaining in the plume was by monitoring the turbulence indicator and by the "feel" of the Cessna's turbulence on the B-23 control surfaces. Fig. 4 shows the concentration of $\mathrm{CCN}$ and the light scattering coefficient during the first penetration of the 1 per cent AgI - acetone plume. As can be seen the aerosol background was somewhat higher than in the experiment described above. The integrating nephelometer confirmed our visual observation of a nearly invisible plume and did not detect it. Similarly the Royco optical counter showed essentially no change with the output remaining within the instrument's noise level. These results strongly suggest that virtually all of the aerosol from the $\mathrm{AgI}-\mathrm{NH}_{4} \mathrm{I}$ - acetone generator were less than $0.1 \mathrm{~m}$ diameter. However, despite their small apparent size, they are moderately efficient $\mathrm{CCN}$. The $\mathrm{CCN}$ concentration approximately doubled during penetration of the plume. Similar wind tunnel measurements using a generator developed by Davis (Grant, 1971) and a solution intermediate with ours ( 3 per cent AgI by weight) shows very much larger particles with more than 30 per cent of the aerosol being larger than $0.1 \mu \mathrm{m}$ diameter.

Besides the much smaller size and reduced activity as CCN (per gram of AgI dispensed) the $\mathrm{NH}_{4} \mathrm{I}$ complexed AgI - acetone solution used in this experiment produced fewer active ice nuclei at -20C. Since the Mee ice nucleus counter lacks careful comparative documentation with other ice nucleus counters only the relative concentrations per gram of AgI are given in Table 1: The results of four experiments made between 1423 and 1522 on October 5, 1972, are listed.

These data show a very satisfactory. degree of experimental consistency between the two pyrotechnic flare experiments and the surprising result that the pyrotechnically produced AgI was approximately four times more effective as an ice nucleus at $-20 \mathrm{C}$ 
than the 1 per cent AgI solution burner and about 36 times more effective than the same burner using an acetone solution containing 10 times as much AgI. The greatiy reduced output from the high concentration AgI solution cannot be readily explained. Postflight examination of the stainless steel solution tanks suggested that part of the explanation might lie in the relative stability of the two solutions since the high concentration tank showed signs of silver loss to the tank walls. However, it is doubtful that this could account for the entire difference. 0.ther workers also appear to have successfully used.similar solutions up to 25 per cent by weight (St. Amand, et al., 1971), although Davis and Schleusener (1972) noted the heavy formation of a silver containing precipitate in 10 per cent solutions after a period of storage in the generator tanks.

The data also show that the $C C N$ production from the flare experiments, when normalized for the amount of AgI consumed, was about a factor of 10 greater than the 1 per cent AgI - acetone solution tests (unfortunately a power failure invalidated the CCN data during the 10 per cent AgI - acetone experiment). Since both generation systems are intended to produce essentially pure uncomplexed AgI (the pyrotechnic AgI aerosol also contains various amounts of fairly insoluble metal oxides) it appears probably that the difference in CCN activity is largely due to the relative sizes of the aerosol.

4. Conclusions.

From the rather limited set of measurements described above a number of tentative conclusions can be drawn concerning these particular particle generators:

(1).. The AgI particles produced pyrotechnically in this airborne system are on order of $0.1 \mu \mathrm{m}$ diameter:

(2) The AgI flare aerosol is sufficiently large that despite their insoluble composition a significant portion are cloud condensation nuclei at 0.5 per cent supersaturation. This result suggests that many of these ice nuclei must act as freezing nuclei rather than as contact or sublimation nuclei. 
(3) The particles produced from the combustion of the $\mathrm{AgI}-\mathrm{NH}_{4} \mathrm{I}$ solution in acetone are smaller than $0.1 \mu \mathrm{m}$ diameter and the number of $\mathrm{CCN}$ produced per gram of AgI consumed is about a tenth of that of the AgI pyrotechnic flares.

(4) The particles produced by the $\mathrm{AgI}-\mathrm{NH}_{4} \mathrm{I}$ - acetone generator did not act as very efficient ice nuclei in the the Mee ice nucleus counter.

(5). While the size intercomparisons between wind tunnel and airborne measurements are probably not strictly valid due to differences in burner design and pyrotechnic composition they suggest that the airborne produced AgI is substantially smaller than the aerosol produced in wind tunnels designed to simulate airborne conditions.

\section{Acknowledgments}

The writers wish to acknowledge the technical assistance of Mr. L. Engel and Mr. M. Miller and the skilled airmanship of Mr. R. Spurling (B-23) and Mr. F, F, O Gladfelder $(c-411)$. The help of Prof. P. V. Hobbs in preparing the paper is also acknowledged. The research was partially supported by the Division of Environmental and Biomedical Research of the U. S. Atomic Energy Commission, and by the RANN Program of the National Science Foundation (Grant GI-31759), Prof. 'P. V. Hobbs, Principal Investigator. 


$$
(19.73)
$$

Alkezweeny, A. J.n Aerosol and Trace Gases Program (under preparation).

Charlson, R. J., N. C. Ahlquist, H. Selvidge and P. B. MacCready, Jr., 1969: Monitoring of atmospheric aerosol parameters with the integrating nephelometer. J. Air Pollution Control, 19, 937-942.

Davis, B. L. and R. A. Schleusener, 1972: A problem in the use of $\mathrm{AgI}-\mathrm{NH}_{4} \mathrm{I}-$ acetone solutions in cloud seeding. J. Appl. Meteor., 11, 234-236.

Dingle, A. N., 1969: Rain Scavenging Studies, Progress Rpt. 6, Dept. of Meteorology, University of Michigan.

Donnan, J. A., D. N. Blair, D. A. Wright, 1971: A wind tunnel/cloud chamber facility for cloud modification research. J. Wea. Mod., 3, 123-133.

Ensor, D. S., R. J. Charlson, N. C. Ahlquist, K. T. Whitby, R. B. Huson and B.Y.H. Liu, 1.972: Multiwavelength nephelometer measurements in Los Angeles smog. J. Coll. and Int. Sci., 39, 242-251.

Grant, L. O., ed., 1971: Proceedings of the Second International Workshop on Condensation and Ice Nuclei, Fort Collins, Colorado, 5-19 August.

Gerber, H. E. and P: A. Allee, 1972: Size distributions of artificial and natural ice nuclei. Preprints of the Third Conference on Weather Modification, June 26-29, 1972, Rapid C⿸广ity, S. D., 24-29.

Henderson, T. J., 1972: Results from comparisons between the field applications of AgI - NaI and AgI - $\mathrm{NH}_{4}$ I solutions in airborne generators on a hail suppression program in Kenya. J. Wea. Mod., 4, 94-101.

Hobbs; P. V., L. E. Radke, A. B. Fraser, J. D. Locatelli, C. E. Robertson, D. G. Atkinson, R. J. Farber, R. R. Weiss and R. C. Easter, 1971: Studies of Winter Cyclonic Storms Over the Cascade Mountains (1970-71). Contributions from the Cloud Physics Group, Res. Rpt. VI, University of Washington, 1-34.

Mossop, S. C. and C. Tuck-Lee, 1968: The composition and size distribution of aerosols produced by burning solutions of $\mathrm{AgI}$ and $\mathrm{NaI}$ in acetone. J. Appl. Meteor., 7, 234-240.

Radke, L. F., and F. M. Turner, 1972: An improved automatic cloud condensation nuclei counter. J. Appl. Meteor., 11, 407-408.

St. Amand, P., W. G. Finnegan, L. Burkhart, 1971: Understanding of the use of simple and complex ice nuclei generated from pyrotechnics and acetone burners. J. Wea. Mod., 3, 31-48.

Steele, R. L., and F. W. Sciacca, 1966: Characteristics of silver iodide ice nuclei originating from anhydrous ammonia silver iodide complexes, Part II. J. Rech. Atmos., 2, 315-326.

Whitby, K. T., and W. E. Clark, 1966: Electric aerosol particle counting and size distribution measuring system for the 0.015 to $1 \mu$ size range. Tellus, $18,573-586$. 
TABLE 1

\begin{tabular}{|c|c|c|c|}
\hline Experiment & $\begin{array}{l}\text { Type of AgI } \\
\text { Generation }\end{array}$ & $\begin{array}{l}\text { Production } \\
\text { Rate }\end{array}$ & $\begin{array}{l}\text { Relative Ice Nucleus } \\
\text { Concentration per } \\
\mathrm{gm} \text { of } \mathrm{AgI} \text { at }-20^{\circ} \mathrm{C}\end{array}$ \\
\hline$\therefore \quad 1$ & $\begin{array}{l}\text { Pyrotechnic } \\
\text { flares }\end{array}$ & $16 \mathrm{gm} / \mathrm{min}$. & 37.5 \\
\hline $2 \quad \therefore$ & $\begin{array}{l}\text { Pyroteçhnic } \\
\text { flares }\end{array}$ & $16 \mathrm{gm} / \mathrm{min}$. & 34.8 \\
\hline$\therefore 3$ & $\begin{array}{l}\text { AgI solution } \\
\text { burner (low } \\
\text { concentration) }\end{array}$ & $33 \mathrm{gm} / \mathrm{min}$. & 8.3 \\
\hline 4 & $\begin{array}{l}\text { AgI solution } \\
\text { burner (high } \\
\text { concentration) }\end{array}$ & $330 \mathrm{gm} / \mathrm{min}$. & 1.0 \\
\hline
\end{tabular}

* Colspan Environmental Systems, Boulder, Colorado. Mixture CSP-009A, Type 600-001. A mixture by weight of $17 \% \mathrm{AgIO}_{3}, 50 \% \mathrm{NH}_{4} \mathrm{IO}_{3}, 15 \% \mathrm{Mg}, 7 \% \mathrm{Al}$, $5 \% \mathrm{Li}_{2} \mathrm{CO}_{3}$ and $6 \%$ plastic resin binder.

A ${ }^{*} *$ mixture in the ratio of $100 \mathrm{gm} \mathrm{AgI,} 31 \mathrm{gm} \mathrm{NH} \mathrm{I}_{4}, 11 \mathrm{gm} \mathrm{H} \mathrm{H}_{2}$ and $13.5 \mathrm{l}$ $\mathrm{CH}_{3} \mathrm{COCH}_{3}$ ( an approximately $1 \%$ solution of $\mathrm{AgI}$ ).

tAll proportions of above increased by 10 except the acetone. 
Figuzin 1

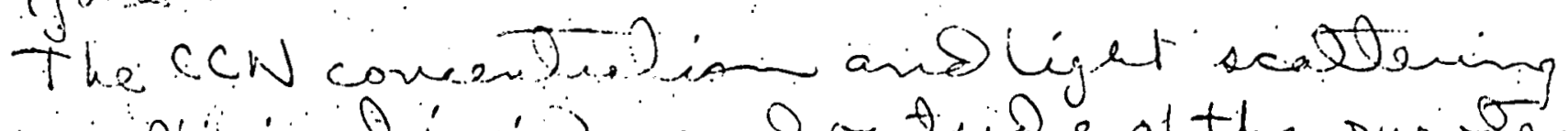

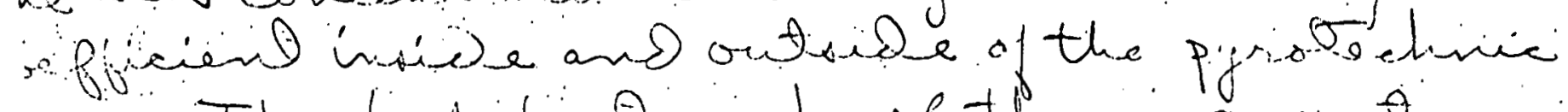

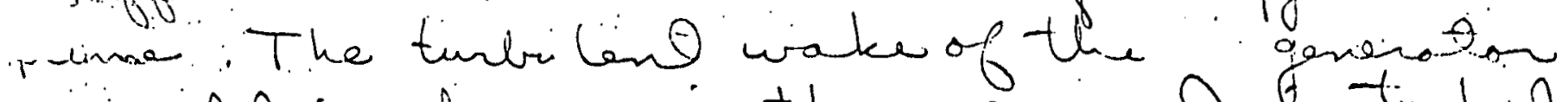
avicraft is ahoun in the mearmes at tientrileme.

TURBULENCE $\left(\mathrm{cm}^{2 / 3} \sec ^{-1}\right)$

B23 CLEAR OF genERETTOR PLUME BZZ IN PLUME

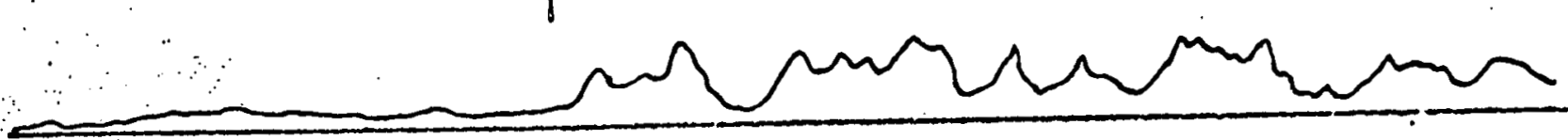

Light Scattiering COEFFICIENT $\left(\times 10^{-5} \mathrm{~m}^{-1}\right)$

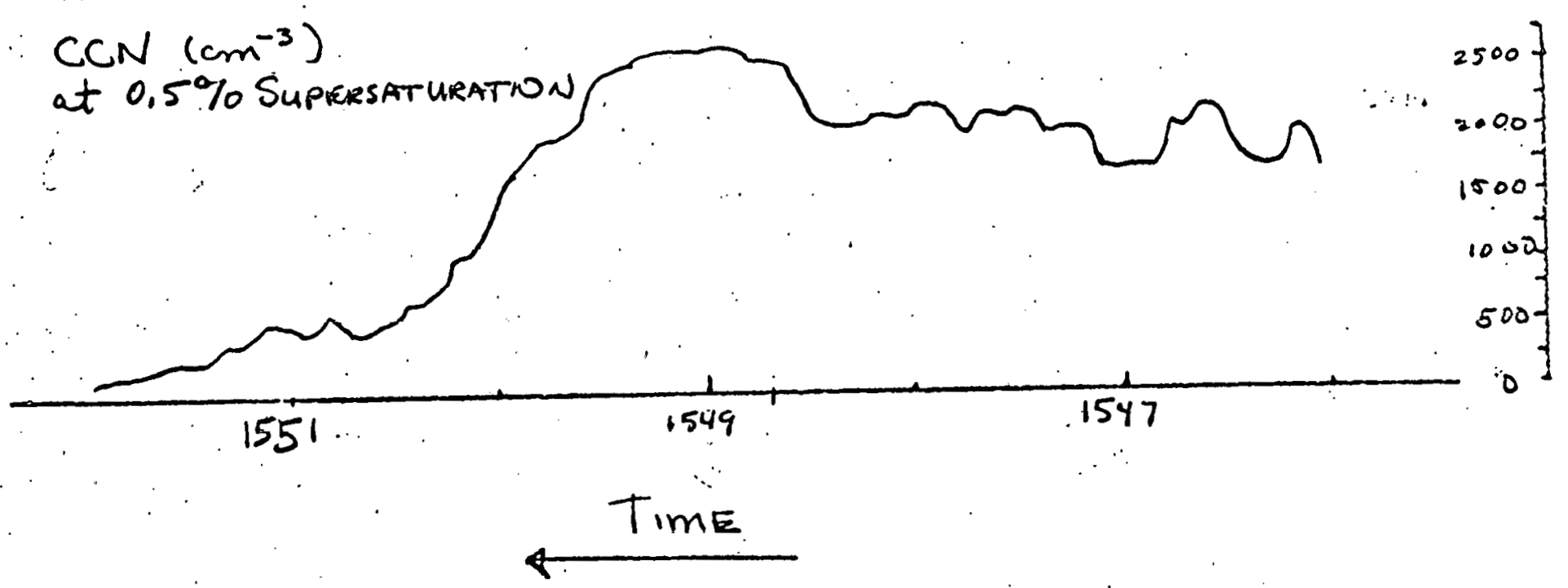




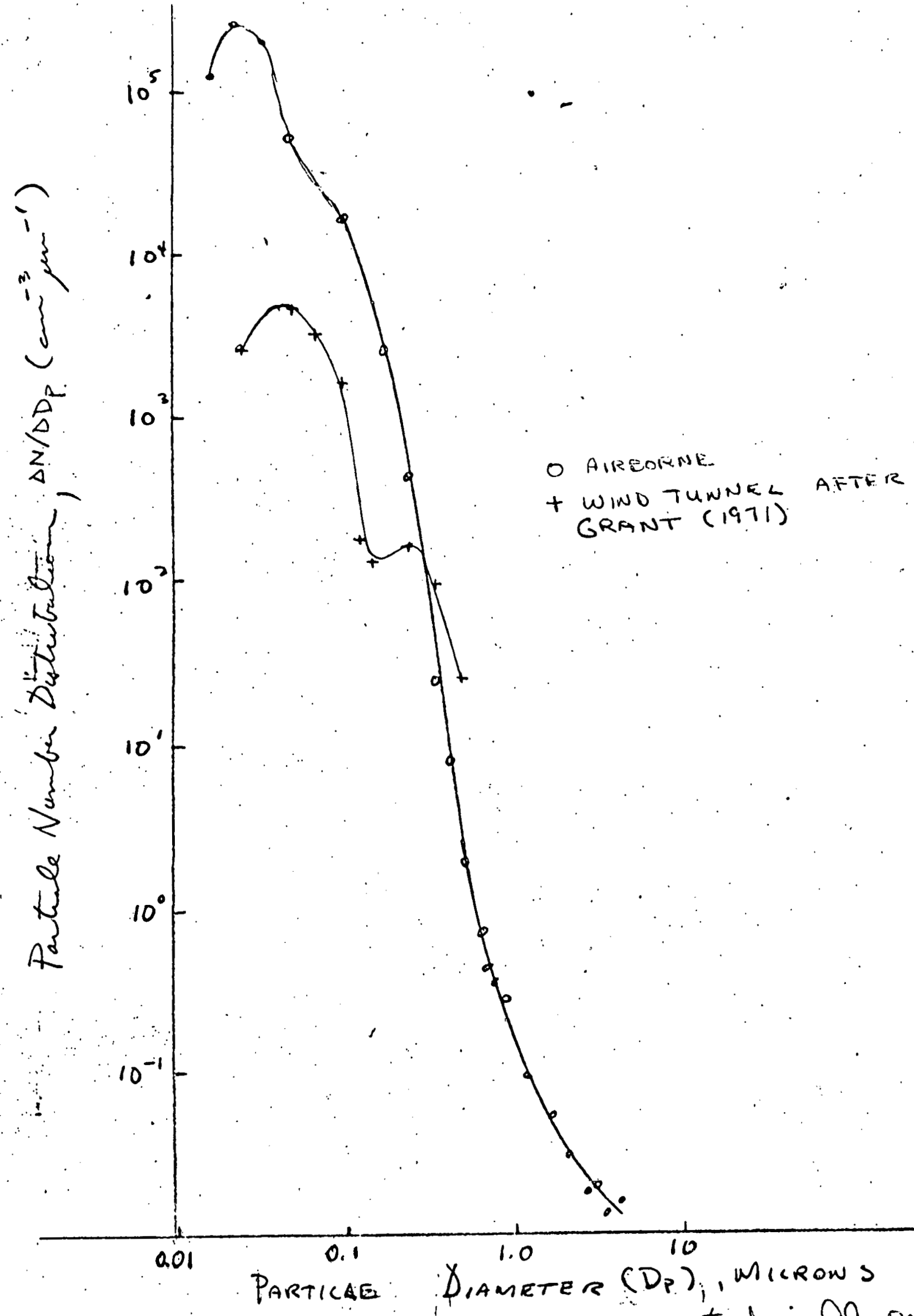

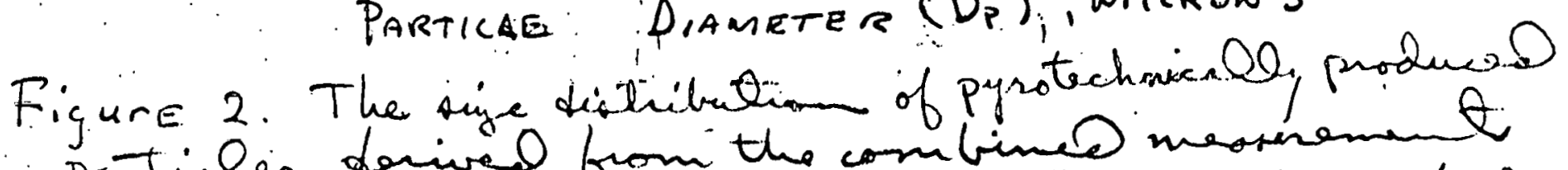

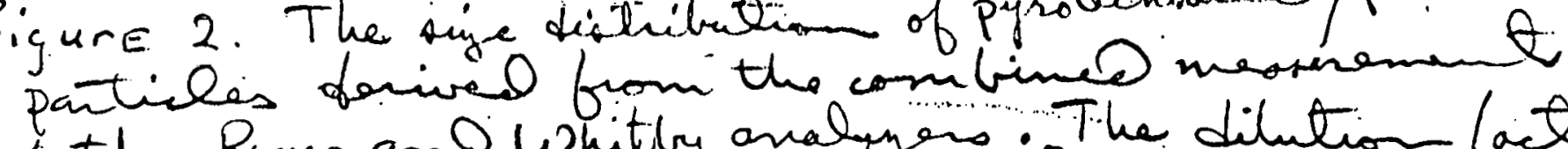

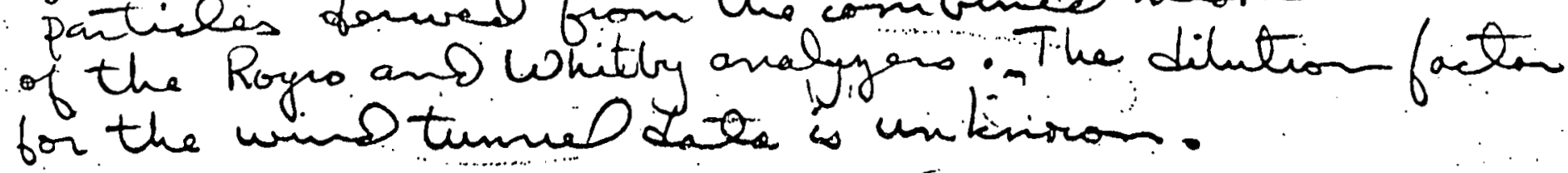




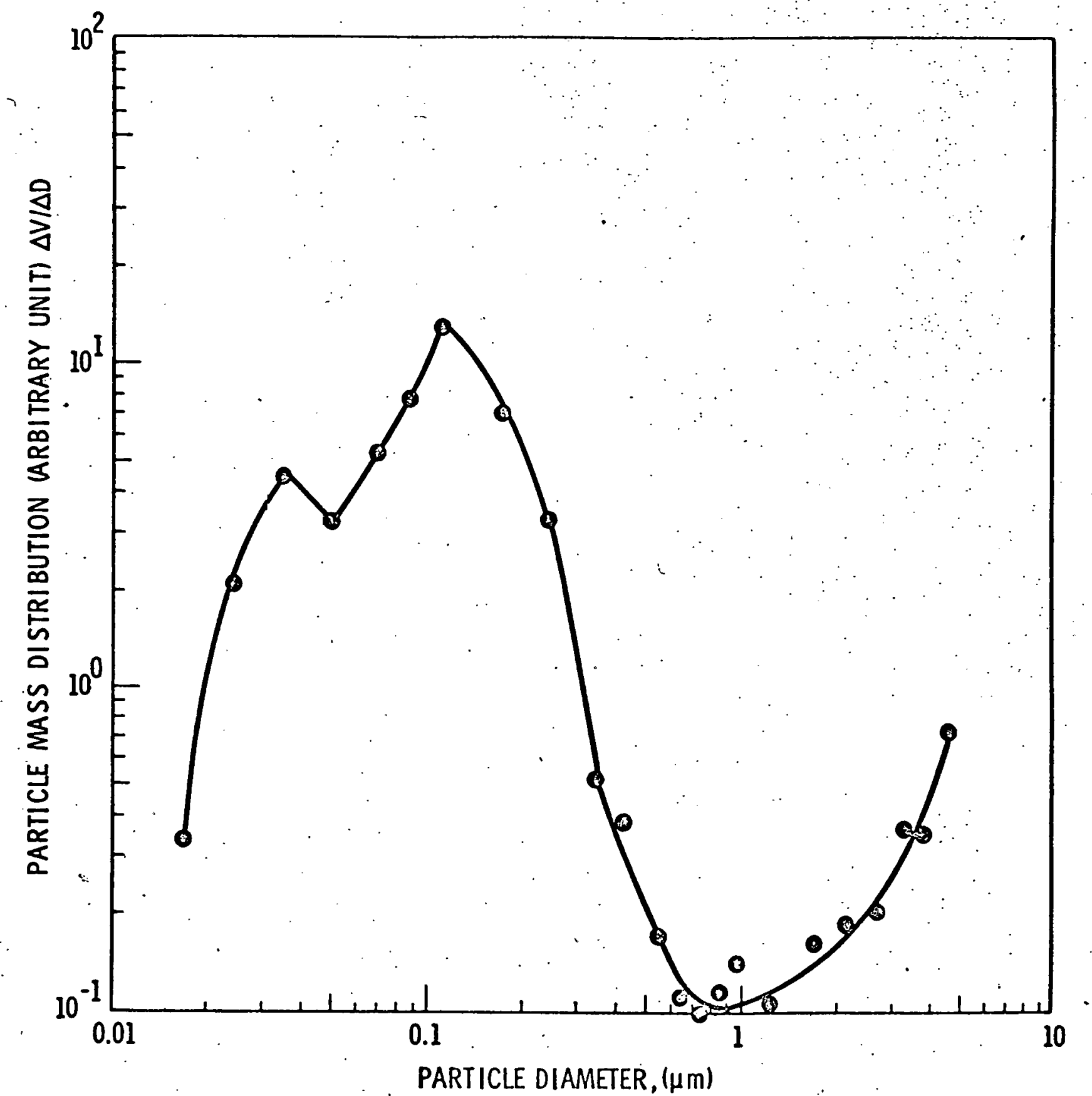

Fics 3 Mas tistribution of particles from the 
"Figuria 4

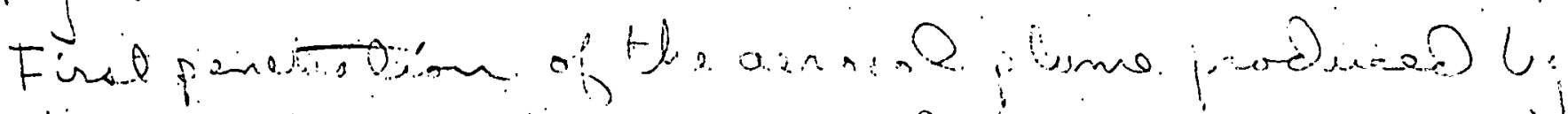

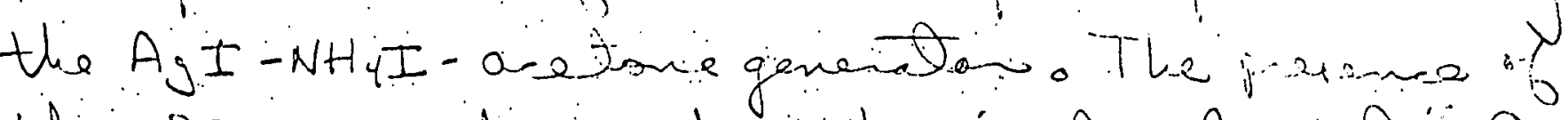
tho B23 in the 411 's wake is Qeanly india.0.0 Uy the tuibulene measmement.

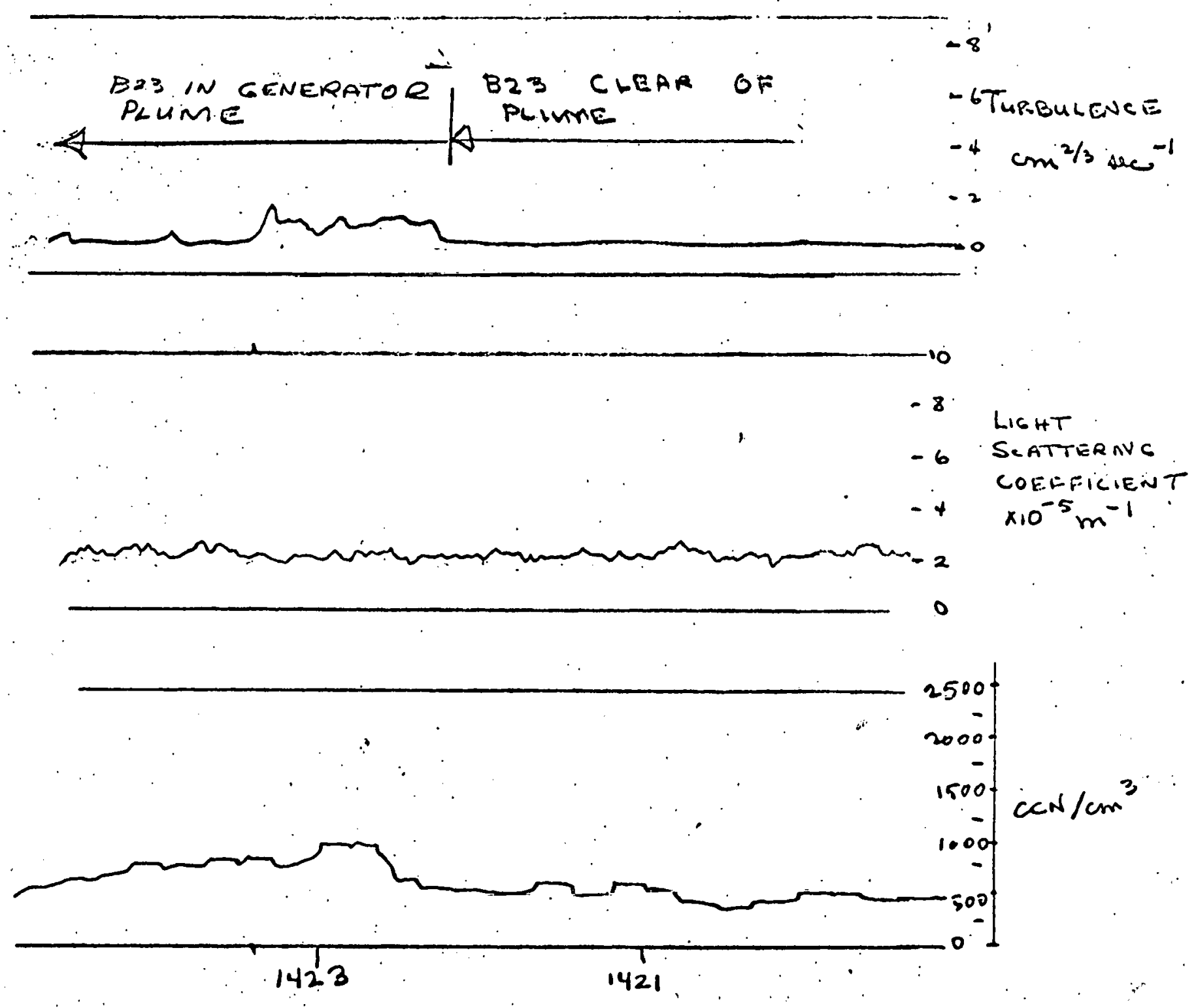

